\title{
LETTERS
}

\section{Training Residents in Outpatient HIV Care}

To the editors:-We appreciate the additional insight provided by Dr. Phillips. We read with interest her study entitled "A multicenter study of internal medicine residents' perceptions of training, competence, and performace in outpatient HIV care." This complimentary study to our own reveals that while medical residents highly value training and experience in outpatient HIV care, both residents and program directors agree that residents are not graduating with competence in this area. We agree that in the face of a growing HIV epidemic and dwindling HIV workforce, a focus on enhanced training in outpatient HIV care is critical. Our studies put together suggest that both pro-

Published online September 29, 2010 gram directors and residents should jointly be involved in the curricular design of new training models. We hope to see innovative outpatient HIV curricula and clinical experiences integrated into residency training programs across the country.

Jennifer Adams, MD, Denver Health and Hospital Authority. 1100 Federal Blvd, Mail Code 3000, Denver, CO, 80204. (e-mail: Jennifer.adams@dhha.org).

$\mathrm{J}$ Gen Intern Med 25(12):1274 DOI: $10.1007 / \mathrm{s} 11606-010-1520-9$

(c) Society of General Internal Medicine 2010 